\title{
The impact of rescue or maintenance therapy with EGFR TKIs for Stage IIIb-IV non-squamous non-small-cell lung cancer patients requiring mechanical ventilation
}

Te-Chun Hsia ${ }^{1,2,3}$, Chih-Yen Tu ${ }^{1,2,4}$ and Hung-Jen Chen ${ }^{1,2,3^{*}}$

\begin{abstract}
Background: The toxicity of epidermal growth factor receptor (EGFR) tyrosine kinase inhibitors (TKIs) is less than that of cytotoxic agents. The reports of dramatic response and improvement in performance status with the use of EGFR TKls may influence a physician's decision-making for patients with non-squamous non-small cell lung cancer (NSCLC) and life-threatening respiratory distress. The aim of this study was to evaluate the outcome of rescue or maintenance therapy with EGFR TKI for stage IIIb-IV non-squamous NSCLC patients requiring mechanical ventilation.

Methods: Eighty-three Asian patients with stage IIII-IV non-squamous NSCLC and who required mechanical ventilation between June 2005 and January 2010 were evaluated.

Results: Of the 83 patients, 16 (19\%) were successfully weaned from the ventilator. The use of EGFR TKI as rescue or maintenance therapy during respiratory failure did not improve the rate of successful weaning (standard care $18 \%$ vs. with EGFR TKI, 22\%; $p=0.81$ ) in univariate and multivariate analyses.

Conclusions: Rescue or maintenance therapy with EGFR TKI for stage IIIb-IV non-squamous NSCLC patients requiring mechanical ventilation was not associated with better outcome. An end-of-life discussion should be an important aspect in the care of this group of patients, since only 19\% were successfully weaned from mechanical ventilation.
\end{abstract}

Keywords: Stage IIIb-IV non-squamous NSCLC, Respiratory failure, EGFR TKI, SAPS II score, SOFA score

\section{Background}

Lung cancer, especially adenocarcinoma, is the leading cause of cancer-related deaths in 2013 [1]. Despite advances in therapy, the five-year survival for stage IIIb-IV patients with metastatic lung cancer is around 2-22\% [2]. Nonetheless, patients with lung cancer sometimes accept mechanical ventilation (MV) support [3-8] because many are unaware of the significant risk of death [9].

Epidermal growth factor receptor (EGFR) is expressed in a large proportion of non-small-cell lung cancer (NSCLC) tumors [10]. Two EGFR mutations (exon 19 deletion and exon 21 L858R substitution) that cluster

\footnotetext{
* Correspondence: Redman0127@gmail.com

'Division of Pulmonary and Critical Care Medicine, China Medical University

Hospital, Taichung, Taiwan

${ }^{2}$ Department of Internal Medicine, China Medical University Hospital,

Taichung, Taiwan

Full list of author information is available at the end of the article
}

around the adenosine- $5^{\prime}$-triphosphate-binding pocket of the EGFR tyrosine kinase (TK) domain are highly responsive to EGFR TK inhibitors (TKIs) like gefitinib or erlotinib [11]. Phase III trials comparing chemotherapy to gefitinib as first-line treatment for advanced NSCLC patients with EGFR-activating mutations have shown that gefitinib significantly improves progression-free survival [12-14]. When samples cannot be enriched for EGFR mutation analysis, never-smokers and Asian nonsquamous NSCLC patients are associated with EGFR mutations and EGFR TKIs responses [15].

Acquired resistance to EGFR TKIs develops in 9.713.3 months in patients with EGFR mutations [16-18]. Because the toxicity of EGFR TKIs is less than that of cytotoxic agents, their use for patients with nonsquamous NSCLC and poor performance status (PS) has also been proven $[19,20]$. 
Lung cancer patients with respiratory failure have extremely poor PS. As reported, dramatic response [21] and improvement in PS [19] with the use of EGFR TKIs may influence a physician's decision-making for patients with non-squamous NSCLC and life-threatening respiratory distress. Lung cancer patients who are ventilatordependent consume considerable resources but have low quality of life in their remaining years. Rescue or maintenance EGFR TKIs can induce apoptosis of lung cancer cells and may favor MV weaning for critical non-squamous NSCLC patients. The objective of this study was to assess the MV weaning rate and outcome of rescue or maintenance therapy with EGFR TKIs for stage IIIb-IV non-squamous NSCLC in Asian patients requiring $\mathrm{MV}$. To date, the present study is first to address this issue.

\section{Methods}

\section{Patient identification}

Lung cancer patients from China Medical University Hospital, a 2000-bed medical center and teaching hospital for referred patients in Taiwan, between June 2005 and January 2010 were included. The hospital's institutional review board approved the study protocol (DMR99-IRB0149) and consent was waived because of the retrospective design. The medical records of 205 lung cancer patients placed on MV because of life-threatening respiratory failure were analyzed. As a care policy in the study hospital, patients who needed MV >24 hours had to be admitted to the intensive care unit (ICU).

Life-threatening respiratory failure was defined as retention of carbon dioxide, hypoxemia, or evidence of respiratory muscle fatigue. Hospice care was defined as a patient refusing any aggressive treatment after endotracheal tube insertion. In case of recurrent respiratory failure requiring $\mathrm{MV}$, only the first was considered. "Ventilator-dependent" was defined as a patient needing MV more than 100 days. In Taiwan, stabilized (ICU) patients needing MV care for more than 21 days are transferred to a respiratory care center. Patients who still require MV with stable condition are subsequently discharged from the hospital and transferred to the chronic respiratory care ward. In this series, no patient transferred to the chronic respiratory care ward since those who required MV more than 100 days was weaned from MV. As such, "ventilator-dependent more than 100 days"

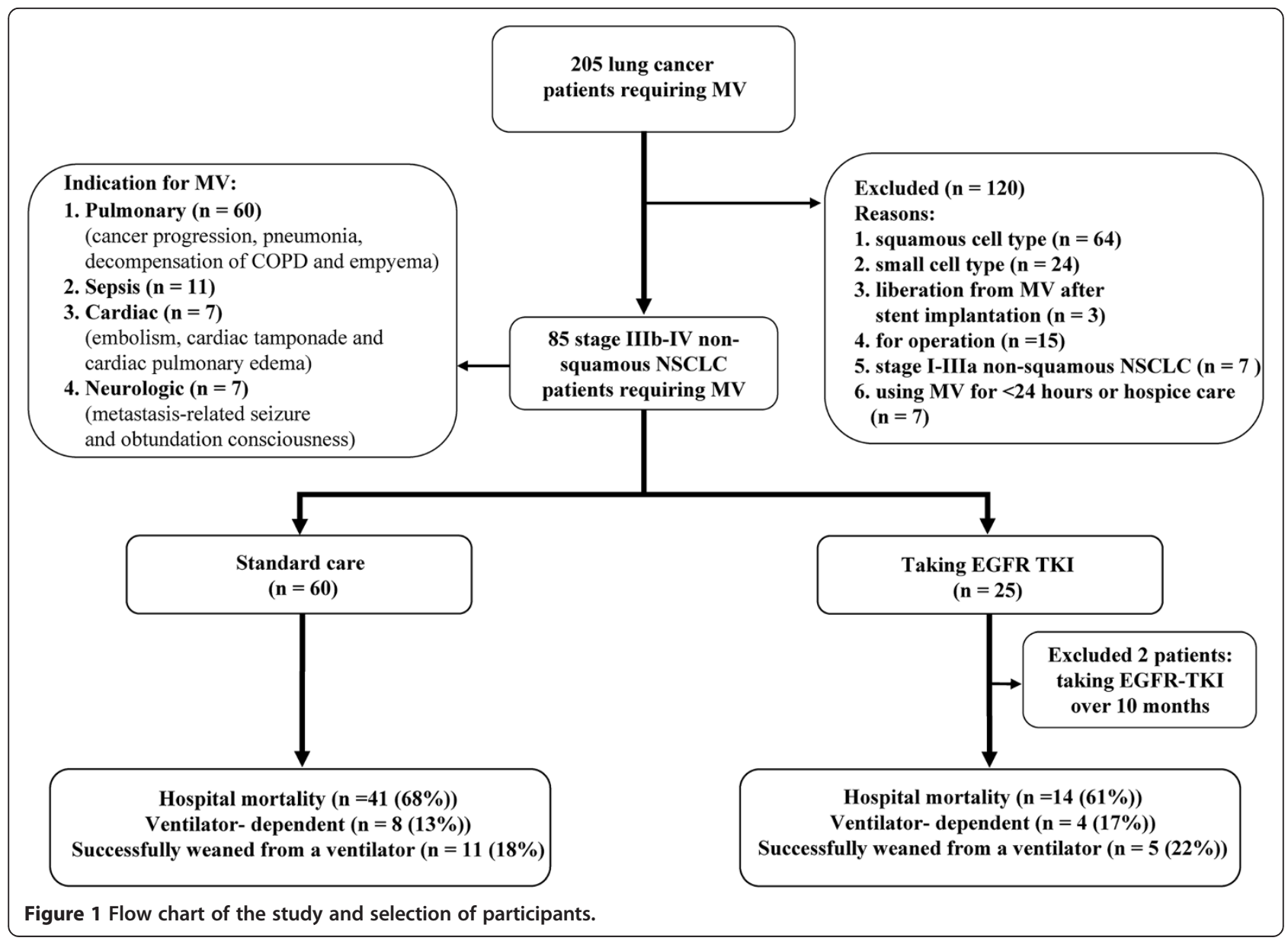


Table 1 Characteristics and prognosis of stage IIIb-IV non-squamous NSCLC patients requiring mechanical ventilation with standard care or EGFR TKIs for rescue therapy

\begin{tabular}{|c|c|c|c|c|}
\hline Variables & All Patients & Standard Care & EGFR TKIs & $p$-value \\
\hline Subjects & 83 & 60 & 23 & \\
\hline Age yrs & $68.0(17)$ & $68.5(18)$ & $68.0(15)$ & 0.84 \\
\hline \multicolumn{5}{|l|}{ Gender } \\
\hline Female & $36(43)$ & $24(40)$ & $12(52)$ & \multirow{2}{*}{0.45} \\
\hline Male & $47(57)$ & $36(60)$ & $11(48)$ & \\
\hline Smoking & $34(41)$ & $25(42)$ & $9(39)$ & 1.00 \\
\hline \multicolumn{5}{|l|}{ Co-morbidities } \\
\hline No & $43(52)$ & $32(53)$ & $11(48)$ & \multirow{2}{*}{0.84} \\
\hline Yes & $40(48)$ & $28(47)$ & $12(52)$ & \\
\hline \multicolumn{5}{|l|}{ ECOG-PS } \\
\hline $0-2$ & $26(31)$ & $17(28)$ & $9(39)$ & \multirow{2}{*}{0.49} \\
\hline $3-4$ & $57(69)$ & $43(72)$ & $14(61)$ & \\
\hline \multicolumn{5}{|l|}{ Type of lung cancer } \\
\hline Adenocarcinoma & $76(92)$ & $55(92)$ & $21(91)$ & \multirow{2}{*}{1.00} \\
\hline Large cell & $7(8)$ & $5(8)$ & $2(9)$ & \\
\hline \multicolumn{5}{|l|}{ Cancer status } \\
\hline Controlled & $11(13)$ & $7(12)$ & $4(17)$ & \multirow{3}{*}{0.76} \\
\hline Uncontrolled, newly diagnosed & $36(43)$ & $27(45)$ & $9(39)$ & \\
\hline Uncontrolled, progression & $36(43)$ & $26(43)$ & $10(44)$ & \\
\hline \multicolumn{5}{|l|}{ Treatment before respiratory failure } \\
\hline Combined therapy & $24(29)$ & $18(30)$ & $6(26)$ & \multirow{4}{*}{0.26} \\
\hline EGFR TKI only & $9(11)$ & $4(7)$ & $5(22)$ & \\
\hline Chemotherapy only & $31(37)$ & $23(38)$ & $8(35)$ & \\
\hline No treatment & $19(23)$ & $15(25)$ & $4(17)$ & \\
\hline \multicolumn{5}{|l|}{ Indication for MV } \\
\hline Pulmonary & $58(70)$ & $41(68)$ & $17(74)$ & \multirow{4}{*}{0.90} \\
\hline Sepsis & $11(13)$ & $9(15)$ & $2(9)$ & \\
\hline Cardiac & $7(8)$ & $5(8)$ & $2(9)$ & \\
\hline Neurologic & $7(8)$ & $5(8)$ & $2(9)$ & \\
\hline APACHE II score, points & $23.0(9)$ & $23.5(11)$ & $23.0(9)$ & 0.86 \\
\hline SAPS II score, points & $54.0(19)$ & $54.5(19)$ & $54.0(23)$ & 0.84 \\
\hline SOFA score, points & $7.0(5)$ & $7.0(4)$ & $7.0(5)$ & 0.70 \\
\hline Use of vasopressors & $39(47)$ & $29(48)$ & $10(44)$ & 0.88 \\
\hline Positive blood culture & $15(18)$ & $12(20)$ & $3(13)$ & 0.54 \\
\hline \multicolumn{5}{|l|}{ Outcomes } \\
\hline Hospital mortality & $55(66)$ & $41(68)$ & $14(61)$ & \multirow{3}{*}{0.81} \\
\hline Ventilator- dependent $>100$ days & $12(15)$ & $8(13)$ & $4(17)$ & \\
\hline Successfully weaned from a ventilator & $16(19)$ & $11(18)$ & $5(22)$ & \\
\hline
\end{tabular}

Data are median (inter-quartile range) for quantitative data and number (\%) for qualitative data.

The $p$ values were calculated by two-sided chi-square and Fisher's exact tests for categorical variables and by the Mann-Whitney $U$ test for continuous variables. Abbreviations: APACHE, Acute Physiology and Chronic Health Evaluation; ECOG-PS, Eastern Cooperative Oncology Group scale, Performance status; EGFR TKIs, Epidermal growth factor receptor tyrosine kinase inhibitor; MV, Mechanical ventilation; SAPS, Simplified Acute Physiology Score; SOFA, Sequential Organ Failure Assessment. 
and "non-survivors" were combined into the same group for analysis.

Based on the inclusion and exclusion criteria (Figure 1), patients accepting stent implantation for obstructive tumors [22], those who used MV for surgery, and those who used MV for <24 hours or hospice care were all excluded to reduce confounding factors. Patients taking gefitinib or erlotinib over 10 months were also excluded from the maintenance therapy group because the possibility of acquired resistance to EGFR TKI could not be ruled out [16-18].

\section{Data collection and definitions}

Demographic, physiologic, and clinical data, including age, sex, smoking history, co-morbidities, and main indication for MV, were collected. The cancer disease characteristics included sub-type, extent of use of the TNM 7th Edition of the Lung Cancer Stage Classification System [2], PS within the preceding week (Eastern Cooperative Oncology Group scale, ECOG-PS) [23], and specific treatments administered before respiratory failure (e.g. surgery, EGFR TKI target therapy, chemotherapy, and/or radiation therapy). The presence of metastasis was also recorded, whether already known or evidenced within the period of ventilator support. The cancer disease status was assessed as controlled or non-controlled (cancer disease progression). Patients with "newly-diagnosed lung cancer" in a non-controlled status were defined as those waiting for a decision to treat or had been treated with less than two cycles of chemotherapy or less than 28 days of EGFR TKI.
Laboratory data obtained within 24 hours of ventilatory support were collected. These included hemoglobin, white blood cell count, platelet count, coagulation profile, levels of blood urea nitrogen, creatinine, and electrolytes, liver function tests, arterial blood gas measurements, and blood cultures.

The severity of the acute illness was assessed using the Acute Physiology and Chronic Health Evaluation (APACHE) II score [24], Simplified Acute Physiology Score (SAPS) II [25], and Sequential Organ Failure Assessment (SOFA) [26] based on data collected within 24 hours of MV. Severe sepsis/septic shock was diagnosed using the definitions of the American College of Chest Physicians/Society of Critical Care Medicine Consensus Conferences [27].

All of the patients were evaluated longitudinally to determine their hospital outcomes. Furthermore, the administration of specific anti-cancer treatments after discharge, i.e., chemotherapy, radiation therapy, and EGFR TKI target therapy, as well as vital status at 18 months, were recorded.

The EGFR TKIs group was defined as patients with nonsquamous NSCLC and respiratory failure treated based on the general principles of critical care and rescue/maintenance EGFR TKIs. The standard care group was defined as patients with non-squamous NSCLC and respiratory failure treated based on the general principles of critical care without radiotherapy, chemotherapy, or EGFR TKIs.

\section{EGFR mutation test}

Most tumor samples were obtained from paraffin-embedded blocks made on initial diagnosis. The DNA sequences of

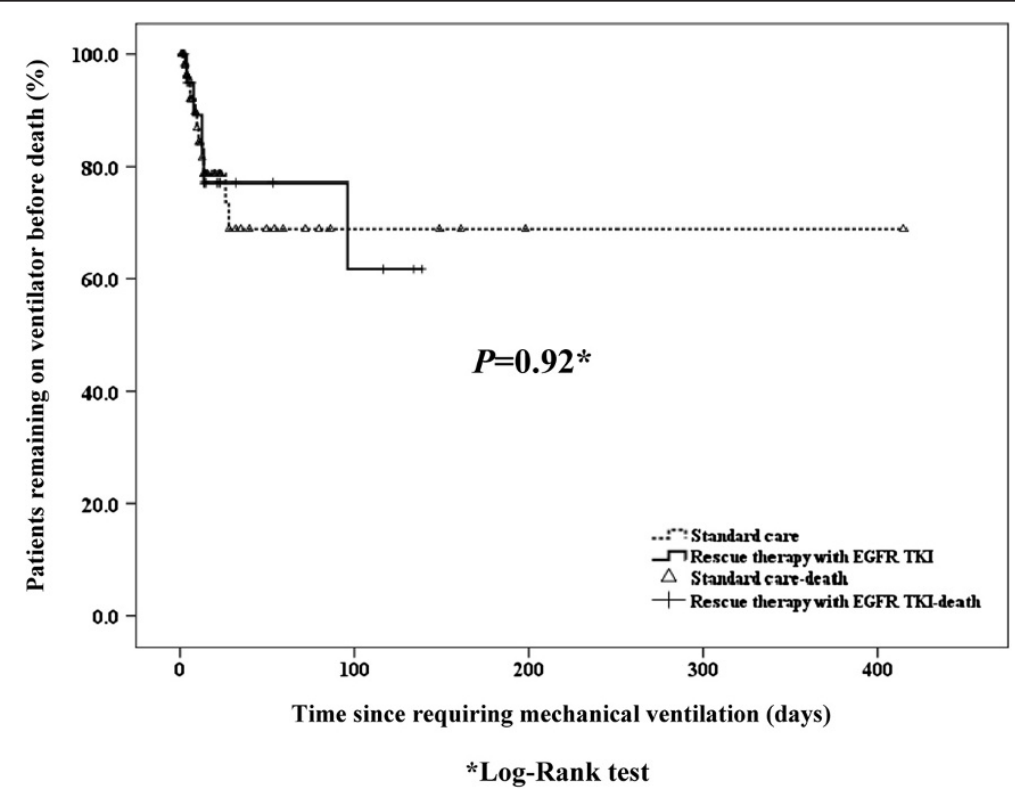

Figure 2 Kaplan-Meier curves of successful weaning from the ventilator between standard care patients and those taking EGFR TKIs for maintenance or rescue therapy. ${ }^{*}$ Log-rank test; EGFR TKIs, Epidermal growth factor receptor tyrosine kinase inhibitors. 
Table 2 Predicting successful weaning from mechanical ventilation

\begin{tabular}{|c|c|c|c|c|c|}
\hline Variables & $\begin{array}{l}\text { Ventilator-dependent }> \\
100 \text { days or non-survivors }\end{array}$ & $\begin{array}{l}\text { Weaned from } \\
\text { the ventilator }\end{array}$ & $\begin{array}{c}\text { Univariate } \\
\text { Analysis OR } \\
(95 \% \mathrm{CI})\end{array}$ & $\begin{array}{c}\text { Multivariate Analysis } \\
\text { (Mode With SOFA) OR } \\
(95 \% \mathrm{Cl})\end{array}$ & $\begin{array}{c}\text { Multivariate Analysis } \\
\text { (Mode With SAPS II) } \\
\text { OR }(95 \% \mathrm{Cl}) \\
\end{array}$ \\
\hline Subjects & 67 & 16 & & & \\
\hline Age yrs & $68.0(16)$ & $71.5(21)$ & $1.01(0.96-1.05)$ & $1.01(0.95-1.07)$ & $1.03(0.97-1.10)$ \\
\hline \multicolumn{6}{|l|}{ Gender } \\
\hline Female & $27(40)$ & $9(56)$ & \multirow{2}{*}{$1.91(0.63-5.73)$} & \multirow{2}{*}{$1.62(0.34-7.85)$} & \multirow{2}{*}{$1.22(0.27-5.59)$} \\
\hline Male & $40(60)$ & $7(44)$ & & & \\
\hline Smoking & $29(43)$ & $5(31)$ & $0.60(0.19-1.90)$ & $1.27(0.23-7.05)$ & $0.83(0.16-4.32)$ \\
\hline \multicolumn{6}{|l|}{ Co-morbidities } \\
\hline No & $34(51)$ & $9(56)$ & \multirow{2}{*}{$0.80(0.27-2.40)$} & \multirow{2}{*}{ - } & \multirow{2}{*}{-} \\
\hline Yes & $33(49)$ & $7(43)$ & & & \\
\hline \multicolumn{6}{|l|}{ ECOG-PS } \\
\hline $0-2$ & $20(30)$ & $6(38)$ & \multirow{2}{*}{$0.71(0.23-2.22)$} & \multirow{2}{*}{-} & \multirow{2}{*}{-} \\
\hline $3-4$ & $47(70)$ & $10(63)$ & & & \\
\hline \multicolumn{6}{|l|}{ Type of lung cancer } \\
\hline Adenocarcinoma & $60(90)$ & $16(100)$ & \multirow{2}{*}{$-^{+}$} & \multirow{2}{*}{-} & \multirow{2}{*}{-} \\
\hline Large cell & $7(10)$ & 0 & & & \\
\hline \multicolumn{6}{|l|}{ Cancer status } \\
\hline Controlled & $9(13)$ & $2(13)$ & & & \\
\hline Uncontrolled, newly diagnosed & $30(45)$ & $6(38)$ & \multirow[t]{2}{*}{$1.29(0.23-7.19)$} & \multirow[t]{2}{*}{-} & \multirow[t]{2}{*}{-} \\
\hline Uncontrolled, progression & $28(42)$ & $8(50)$ & & & \\
\hline \multicolumn{6}{|c|}{ Treatment before respiratory failure } \\
\hline Combined therapy & $21(31)$ & $3(19)$ & & & \\
\hline EGFR TKI only & $6(9)$ & $3(19)$ & \multirow{3}{*}{$2.04(0.47-8.91)$} & \multirow{3}{*}{$2.18(0.45-10.53)$} & \multirow{3}{*}{$1.70(0.36-7.99)$} \\
\hline Chemotherapy only & $24(36)$ & $7(44)$ & & & \\
\hline No treatment & $16(24)$ & $3(19)$ & & & \\
\hline \multicolumn{6}{|l|}{ Indication for MV } \\
\hline Pulmonary & $48(72)$ & $10(63)$ & & & \\
\hline Sepsis & $9(13)$ & $2(13)$ & \multirow{3}{*}{$0.80(0.09-7.40)$} & \multirow{3}{*}{-} & \multirow{3}{*}{-} \\
\hline Cardiac & $6(9)$ & $1(6)$ & & & \\
\hline Neurologic & $4(6)$ & $3(19)$ & & & \\
\hline APACHE II score, points & $25.0(12)$ & $21.0(7)$ & $0.91(0.82-1.00)$ & - & - \\
\hline SAPS II score, points & $55.0(23)$ & $46.5(15)$ & $0.94(0.89-0.99)^{*}$ & - & $0.92(0.86-0.99)^{*}$ \\
\hline SOFA score, points & $8.0(4)$ & $6.0(4)$ & $0.80(0.65-0.98)^{*}$ & $0.66(0.46-0.94)^{*}$ & - \\
\hline Use of vasopressors & $33(49)$ & $6(38)$ & $0.62(0.20-1.89)$ & $3.77(0.57-25.07)$ & $1.35(0.33-5.50)$ \\
\hline Positive blood culture & $13(19)$ & $2(13)$ & $0.59(0.12-2.94)$ & - & - \\
\hline Taking EGFR TKI & $18(27)$ & $5(31)$ & $1.24(0.38-4.06)$ & $0.98(0.26-3.77)$ & $1.14(0.30-4.27)$ \\
\hline
\end{tabular}

Data are median (inter-quartile range) for quantitative data and number (\%) for qualitative data.

The $p$ values were calculated by two-sided chi-square and Fisher's exact tests for categorical variables and by the Mann-Whitney $U$ test for continuous variables. OR, odds ratio (See Tables 1 for expansion of other abbreviations).

${ }^{+}$Difficult check due to statistical convergence problem.

${ }^{*} p<0.05$.

exons 19 and 21 of EGFR were determined by direct forward and reverse sequencing of the polymerase chain reaction (PCR) product from nested PCR reactions, as described previously [28].

\section{Statistical analysis}

Continuous variables were reported as median (interquartile range, IQR) and categorical variables as number (percentage). The SAPS II and the SOFA scores were 
expressed in points while $p$ values were calculated using two-sided chi-square and Fisher's exact tests for categorical variables and the Mann-Whitney $U$ test for continuous variables. The curves of ventilator weaning were obtained using the Kaplan-Meier method and compared using the Log-Rank test.

Univariate and multivariate analyses were performed to identify factors associated with weaning from MV. Variables selected by univariate analysis $(p \leq 0.5)$ and those considered as clinically relevant (age) were entered into a logistic regression model. Results were expressed as odds ratios (ORs), with their $95 \%$ confidence intervals (95\% CIs). Statistical significance was set at $p<0.05$. All statistical analyses were performed using the SPSS software, version 17.0 (SPSS Inc., Chicago, IL, USA).

\section{Results}

Of 205 potentially eligible patients with lung cancer requiring MV, 64 with squamous cell type, 24 with small cell type, 3 with liberation from MV after stent implantation, 15 who used MV for operation, seven with stage I-IIIa non-squamous NSCLC, seven who used MV for $<24$ hours or hospice care, and two taking EGFR TKIs over 10 months were excluded. The resulting sample included 83 stage IIIb-IV non-squamous NSCLC Asian patients with lifethreatening respiratory failure. Twenty-three 23 (28\%) used gefitinib or erlotinib for rescue or maintenance therapy and $60(72 \%)$ had standard care (Figure 1). Their baseline clinical characteristics were summarized in Table 1.

The main reasons for MV were pulmonary problems (e.g. lung cancer progression, pneumonia, decompensation of chronic obstructive pulmonary disease, and empyema) $(n=58 ; 70 \%)$, sepsis $(n=11 ; 13 \%)$, cardiovascular disease (i.e. embolism, cardiac tamponade, cardiac pulmonary edema) $(\mathrm{n}=7 ; 8 \%)$, and neurologic problems (i.e. metastasis-related seizure and obtunded consciousness) $(\mathrm{n}=7 ; 8 \%)$. Some patients had more than one reason for MV (Figure 1).

Sixteen patients (19\%) were successfully weaned from the ventilator and $67(81 \%)$ remained ventilator-dependent or died (Figure 1). No patient was transferred to the chronic respiratory care ward since those who required MV more than 100 days were successfully weaned from MV. Eight of the 16 patients successfully weaned were discharged from the hospital and received specific anti-cancer treatments. Two patients received chemotherapy and EGFR TKIs, three had chemotherapy, and three had EGFR TKIs only. All of the patients died within 415 days.

There were no significant differences in baseline clinical characteristics, including APACHE II, SAPS II, and SOFA scores between the standard care patients and those who took gefitinib or erlotinib as rescue or maintenance therapy during the period of respiratory failure. There was no significant difference in outcomes (hospital mortality, ventilator-dependence $>100$ days, and successful weaning) between the two groups (Table 1). KaplanMeier curves of successful weaning from MV with Log-Rank test also revealed no significant differences $(p=0.92)$ (Figure 2).

The main laboratory and physiologic variables were recorded and compared by univariate and multivariate analysis between "ventilator-dependent $>100$ days/nonsurvivors" and "successfully weaned from the ventilator" during the period of respiratory failure (Table 2). Variables that differed significantly were worse severity scores (SOFA or SAPS II scores), not taking EGFR TKIs.

Eight (35\%) of 23 patients taking EGFR TKIs for maintenance or rescue therapy had samples enriched for EGFR mutation analysis. Three patients had exon 19 deletions, three had L858R, one had double mutation of exon19 deletions and L858R, and one was wild-type. Patients who were never-smokers and/or positive for EGFR mutation accounted for $72 \%$ of those who were "ventilatordependent $>100$ days or non-survivors" (Table 3). Statistical analysis was not performed in Table 3 because the sample size was too small.

\section{Discussion}

To date, this study is the largest investigation on stage IIIb-IV non-squamous NSCLC patients requiring MV. This study is also the first to review rescue or maintenance therapy with EGFR TKIs in non-squamous NSCLC patients with respiratory failure. Based on the findings, rescue or maintenance therapy with EGFR TKIs for stage IIIb-IV non-squamous NSCLC patients requiring MV is not associated with better outcome.

When acute life-threatening respiratory failure develops in a patient with lung cancer, physicians are doubtful

Table 3 EGFR mutation, non-smoking percentage, and SAPS II and SOFA scores of patients taking EGFR TKIs for rescue/maintenance therapy $(n=23)$

\begin{tabular}{lcc}
\hline Variables & $\begin{array}{c}\text { Ventilator-dependent }> \\
\text { 100 days or non-survivors }\end{array}$ & $\begin{array}{c}\text { Weaned } \\
\text { from the } \\
\text { ventilator }\end{array}$ \\
\hline Subjects & 6 positive & 5 \\
$\begin{array}{l}\text { EGFR mutation status } \\
\text { of } 8 \text { samples }\end{array}$ & 1 negative & 1 positive \\
*Smoking & 4 & 1 \\
Nonsmoking & 7 & 3 \\
Positive EGFR mutation + & $13(72)$ & $4(80)$ \\
nonsmoking & & $46.0(20.5)$ \\
SAPS II score & $54.0(23.0)$ & $5.0(3.5)$ \\
\hline SOFA score & $8.0(4.5)$ & \\
\hline
\end{tabular}

*Excluding patients receiving EGFR mutation test.

Data are median (inter-quartile range) for quantitative data and number (\%) for qualitative data.

See Tables 1 for abbreviations. 
about the wisdom of endotracheal intubation with MV support. This is because lung cancer patients have a special condition in which tumor extension during treatment of reversible problems may preclude successful weaning from MV. Although "do not resuscitate" is recommended by physicians for critically ill lung cancer patients, patients also want to try chemotherapy [29] or new anti-cancer medications [30] and have accepted MV support [3-8].

The results reveal that $69 \%$ of patients with ECOG-PS 3 or 4 are admitted for MV (Table 1), suggesting a rather poor outcome, with successful weaning rates of $19 \%$ for stage IIIb-IV non-squamous NSCLC patients, similar to those of studies by Reiner et al. [5] and Soares et al. [7]. Only eight $(10 \%)$, or half of the surviving patients discharged from the hospital, have received specific anticancer treatments.

In this series, the "ventilator-dependent $>100$ days" and "non-survivors" have been combined into the same group because their prognoses preclude performing endotracheal intubation (Table 2). Although individual outcome may be difficult to predict, those with lower SAPS II $(p=0.03)$ or SOFA $(p=0.02)$ scores have higher rates of weaning from the ventilator. These results here are similar to those of Toffart et al. [31] and Roques et al. [6].

Undoubtedly, gefitinib and erlotinib have powerful antitumor activity and are superior to chemotherapy in patients with advanced non-squamous NSCLC with EGFR mutations $[14,17]$. However, despite similar baseline clinical characteristics in the study groups during the period of respiratory failure, intake of EGFR TKIs as rescue or maintenance therapy does not lead to a better rate of weaning from the MV (Table 1). This is because the severity of acute illness scores or organ dysfunction has a larger impact on the prognosis of critically ill lung cancer patients than tumor-related factors [31]. In 23 patients taking EGFR TKIs for rescue/maintenance therapy, the "ventilator-dependent $>100$ days/non-survivors" group also has higher SAPS II and SOFA scores, which corroborate this (Table 3).

The current study has several limitations. First, it is a single-center study, so the generalizability of the results to other hospitals is unknown. Second, this is a retrospective study. The sample size of the group taking EGFR TKIs for rescue or maintenance therapy is small. However, a large prospective, randomized trial to confirm the results in terms of maintenance or rescue therapy with gefitinib or erlotinib for stage IIIb-IV non-squamous NSCLC patients requiring $\mathrm{MV}$ will probably not be feasible. Third, only $35 \%(8 / 23)$ of samples were enriched for EGFR mutation analysis. Otherwise, the percentage of never-smokers and/ or those positive for EGFR mutation was $72 \%$ in the "ventilator-dependent $>100$ days/non-survivors" group. The high percentage $(72 \%)$ against the thought of poor outcome is related to ineffective EGFR TKI.
Why did $29 \%$ of patients receive EGFR TKI for rescue or maintenance therapy but others did not? The main reason may be that clinicians expect EGFR TKIs to be effective by the status of never-smokers and non-squamous NSCLC Asian patients [15]. In the study hospital, EGFR mutation could not be checked until 2009. In the standard care group, 20\% of patients stopped using EGFR TKIs after respiratory failure because it was ineffective or because of interstitial pneumonitis. With a high selection for EGFR TKI treatment, the use of EGFR TKIs does not lead to better outcomes if the patient's acute severity score reaches a critical level.

\section{Conclusions}

Rescue or maintenance therapy with EGFR TKI for stage IIIb-IV non-squamous NSCLC patients requiring MV was not associated with better outcome. An end-of-life discussion should be an important aspect in the care of this group of patients since only $19 \%$ were successfully weaned from MV.

\section{Abbreviations}

APACHE: Acute physiology and chronic health evaluation; ECOG-PS: Eastern cooperative oncology group scale, performance status; EGFR TKIs: Epidermal growth factor receptor tyrosine kinase inhibitor; ICU: Intensive care unit; MV: Mechanical ventilation; NSCLC: Non-small cell lung cancer; SAPS: Simplified acute physiology score; SOFA: Sequential organ failure assessment; COPD: Chronic obstructive pulmonary disease.

\section{Competing interests}

The authors declare that they have no competing interests

\section{Authors' contributions}

TCH, CYT and HJC designed the study and interpreted the results. HJC drafted the manuscript. All authors edited and approved the final manuscript.

\section{Acknowledgments}

This study is partial supported by Taiwan Ministry of Health and Welfare Clinical Trial and Research Center of Excellence (DOH102-TD-B-111-004). The authors thank Chia-Ing Li for her technical help in the statistical analysis.

\section{Author details}

${ }^{1}$ Division of Pulmonary and Critical Care Medicine, China Medical University Hospital, Taichung, Taiwan. ${ }^{2}$ Department of Internal Medicine, China Medical University Hospital, Taichung, Taiwan. ${ }^{3}$ Department of Respiratory Therapy, China Medical University, Taichung, Taiwan. ${ }^{4}$ Department of Life Sciences, National Chung Hsing University, Taichung, Taiwan.

Received: 18 December 2013 Accepted: 9 July 2014

Published: 16 July 2014

\section{References}

1. Siegel R, Naishadham D, Jemal A: Cancer statistics, 2013. CA Cancer J Clin 2013, 63:11-30.

2. Goldstraw P, Crowley J, Chansky K, Giroux DJ, Groome PA, Rami-Porta R, Postmus PE, Rusch V, Sobin L: The IASLC lung cancer staging project: proposals for the revision of the TNM stage groupings in the forthcoming (seventh) edition of the TNM classification of malignant tumours. J Thorac Oncol 2007, 2:706-714.

3. Adam AK, Soubani AO: Outcome and prognostic factors of lung cancer patients admitted to the medical intensive care unit. Eur Respir J 2008, 31:47-53. 
4. Ewer MS, Ali MK, Atta MS, Morice RC, Balakrishnan PV: Outcome of lung cancer patients requiring mechanical ventilation for pulmonary failure. JAMA 1986, 256:3364-3366.

5. Reichner CA, Thompson JA, O'Brien S, Kuru T, Anderson ED: Outcome and code status of lung cancer patients admitted to the medical ICU. Chest 2006, 130:719-723.

6. Roques S, Parrot A, Lavole A, Ancel PY, Gounant V, Djibre M, Fartoukh M: Six-month prognosis of patients with lung cancer admitted to the intensive care unit. Intensive Care Med 2009, 35:2044-2050.

7. Soares M, Darmon M, Salluh Jl, Ferreira CG, Thiery G, Schlemmer B, Spector N, Azoulay E: Prognosis of lung cancer patients with life-threatening complications. Chest 2007, 131:840-846.

8. Lin YC, Tsai YH, Huang CC, Hsu KH, Wang SW, Tsao TC, Lin MC: Outcome of lung cancer patients with acute respiratory failure requiring mechanical ventilation. Respir Med 2004, 98:43-51.

9. Griffin JP, Nelson JE, Koch KA, Niell HB, Ackerman TF, Thompson M, Cole FH: End-of-life care in patients with lung cancer. Chest 2003, 123:312S-331S.

10. Rusch V, Baselga J, Cordon-Cardo C, Orazem J, Zaman M, Hoda S, McIntosh J, Kurie J, Dmitrovsky E: Differential expression of the epidermal growth factor receptor and its ligands in primary non-small cell lung cancers and adjacent benign lung. Cancer Res 1993, 53:2379-2385.

11. Paez JG, Janne PA, Lee JC, Tracy S, Greulich H, Gabriel S, Herman P, Kaye FJ, Lindeman N, Boggon TJ, Naoki K, Sasaki H, Fujii Y, Eck MJ, Sellers WR, Johnson BE, Meyerson M: EGFR mutations in lung cancer: correlation with clinical response to gefitinib therapy. Science 2004, 304:1497-1500.

12. Maemondo M, Inoue A, Kobayashi K, Sugawara S, Oizumi S, Isobe H, Gemma A, Harada M, Yoshizawa H, Kinoshita I, Fujita Y, Okinaga S, Hirano H, Yoshimori K, Harada T, Ogura T, Ando M, Miyazawa H, Tanaka T, Saijo Y, Hagiwara K, Morita S, Nukiwa T: Gefitinib or chemotherapy for non-small-cell lung cancer with mutated EGFR. N Engl J Med 2010, 362:2380-2388.

13. Mitsudomi T, Morita S, Yatabe Y, Negoro S, Okamoto I, Tsurutani J, Seto T, Satouchi M, Tada H, Hirashima T, Asami K, Katakami N, Takada M, Yoshioka H, Shibata K, Kudoh S, Shimizu E, Saito H, Toyooka S, Nakagawa K, Fukuoka M: Gefitinib versus cisplatin plus docetaxel in patients with non-small-cell lung cancer harbouring mutations of the epidermal growth factor receptor (WJTOG3405): an open label, randomised phase 3 trial. Lancet Oncol 2010, 11:121-128.

14. Mok TS, Wu YL, Thongprasert S, Yang CH, Chu DT, Saijo N, Sunpaweravong $P$, Han B, Margono B, Ichinose Y, Nishiwaki Y, Ohe Y, Yang JJ, Chewaskulyong B, Jiang $H$, Duffield EL, Watkins CL, Armour AA, Fukuoka M: Gefitinib or carboplatin-paclitaxel in pulmonary adenocarcinoma. N Engl J Med 2009, 361:947-957.

15. Thatcher N, Chang A, Parikh P, Rodrigues Pereira J, Ciuleanu T, von Pawel J, Thongprasert S, Tan EH, Pemberton K, Archer V, Carroll K: Gefitinib plus best supportive care in previously treated patients with refractory advanced non-small-cell lung cancer: results from a randomised, placebo-controlled, multicentre study (iressa survival evaluation in lung cancer). Lancet 2005, 366:1527-1537.

16. Inoue A, Suzuki T, Fukuhara T, Maemondo M, Kimura Y, Morikawa N, Watanabe H, Saijo Y, Nukiwa T: Prospective phase II study of gefitinib for chemotherapy-naive patients with advanced non-small-cell lung cancer with epidermal growth factor receptor gene mutations. J Clin Oncol 2006, 24:3340-3346.

17. Rosell R, Moran T, Queralt C, Porta R, Cardenal F, Camps C, Majem M, Lopez-Vivanco G, Isla D, Provencio M, Insa A, Massuti B, Gonzalez-Larriba JL, Paz-Ares L, Bover I, Garcia-Campelo R, Moreno MA, Catot S, Rolfo C, Reguart N, Palmero R, Sannchez JM, Bastus R, Mayo C, Bertran-Alamillo J, Molina MA, Sanchez JJ, Taron M: Screening for epidermal growth factor receptor mutations in lung cancer. N Engl J Med 2009, 361:958-967.

18. Sequist LV, Martins RG, Spigel D, Grunberg SM, Spira A, Janne PA, Joshi VA McCollum D, Evans TL, Muzikansky A, Kuhlmann GL, Han M, Goldberg JS, Settleman J, lafrate AJ, Engelman JA, Haber DA, Johnson BE, Lynch TJ: First-line gefitinib in patients with advanced non-small-cell lung cancer harboring somatic EGFR mutations. J Clin Oncol 2008, 26:2442-2449.

19. Inoue A, Kobayashi K, Usui K, Maemondo M, Okinaga S, Mikami I, Ando M, Yamazaki K, Saijo Y, Gemma A, Miyazawa H, Tanaka T, Ikebuchi K, Nukiwa T, Morita S, Hagiwara K: First-line gefitinib for patients with advanced non-small-cell lung cancer harboring epidermal growth factor receptor mutations without indication for chemotherapy. J Clin Oncol 2009, 27:1394-1400.
20. Yang CH, Shih JY, Chen KC, Yu CJ, Yang TY, Lin CP, Su WP, Gow CH, Hsu C, Chang GC, Yang PC: Survival outcome and predictors of gefitinib antitumor activity in east Asian chemo-naive patients with advanced non-small cell lung cancer. Cancer 2006, 107:1873-1882.

21. Cho D, Kocher O, Tenen DG, Halmos B, Lee JC, Meyerson ML, Janne PA: Unusual cases in multiple myeloma and a dramatic response in metastatic lung cancer: CASE 4. Mutation of the epidermal growth factor receptor in an elderly man with advanced, gefitinib-responsive, non-small-cell lung cancer. J Clin Oncol 2005, 23:235-237.

22. Lin SM, Lin TY, Chou CL, Chen HC, Liu CY, Wang CH, Lin HC, Yu CT, Lee KY, Kuo HP: Metallic stent and flexible bronchoscopy without fluoroscopy for acute respiratory failure. Eur Respir J 2008, 31:1019-1023.

23. Oken MM, Creech RH, Tormey DC, Horton J, Davis TE, McFadden ET, Carbone PP: Toxicity and response criteria of the eastern cooperative oncology group. Am J Clin Oncol 1982, 5:649-656.

24. Knaus WA, Draper EA, Wagner DP, Zimmerman JE: APACHE II: a severity of disease classification system. Crit Care Med 1985, 13:818-829.

25. Le Gall JR, Lemeshow S, Saulnier F: A new simplified acute physiology score (SAPS II) based on a European/north American multi-center study. JAMA 1993, 270:2957-2963.

26. Vincent JL, Moreno R, Takala J, Willatts S, De Mendonca A, Bruining $H_{\text {, }}$ Reinhart CK, Suter PM, Thijs LG: The SOFA (sepsis-related organ failure assessment) score to describe organ dysfunction/failure. On behalf of the working group on sepsis-related problems of the European society of intensive care medicine. Intensive Care Med 1996, 22:707-710.

27. Bone RC, Balk RA, Cerra FB, Dellinger RP, Fein AM, Knaus WA, Schein RM, Sibbald WJ: Definitions for sepsis and organ failure and guidelines for the use of innovative therapies in sepsis. The ACCP/SCCM consensus conference committee. American college of chest physicians/society of critical care medicine. Chest 1992, 101:1644-1655.

28. Huang SF, Liu HP, Li LH, Ku YC, Fu YN, Tsai HY, Chen YT, Lin YF, Chang WC, Kuo HP, Wu YC, Chen YR, Tsai SF: High frequency of epidermal growth factor receptor mutations with complex patterns in non-small cell lung cancers related to gefitinib responsiveness in Taiwan. Clin Cancer Res 2004, 10:8195-8203.

29. Darmon M, Thiery G, Ciroldi M, de Miranda S, Galicier L, Raffoux E, Le Gall $\mathrm{JR}$, Schlemmer B, Azoulay E: Intensive care in patients with newly diagnosed malignancies and a need for cancer chemotherapy. Crit Care Med 2005, 33:2488-2493.

30. Earle CC, Neville BA, Landrum MB, Ayanian JZ, Block SD, Weeks JC: Trends in the aggressiveness of cancer care near the end of life. J Clin Oncol 2004, 22:315-321.

31. Toffart AC, Minet C, Raynard B, Schwebel C, Hamidfar-Roy R, Diab S, Quetant S, Moro-Sibilot D, Azoulay E, Timsit JF: Use of intensive care in patients with non-resectable lung cancer. Chest 2011, 139:101-108.

doi:10.1186/1471-2253-14-55

Cite this article as: Hsia et al:: The impact of rescue or maintenance therapy with EGFR TKIs for Stage IIIb-IV non-squamous non-small-cell lung cancer patients requiring mechanical ventilation. BMC Anesthesiology 2014 14:55.

\section{Submit your next manuscript to BioMed Central and take full advantage of:}

- Convenient online submission

- Thorough peer review

- No space constraints or color figure charges

- Immediate publication on acceptance

- Inclusion in PubMed, CAS, Scopus and Google Scholar

- Research which is freely available for redistribution 